\title{
PERILAKU POLITIK GEREJA KRISTEN EVANGELIS (GKE) DALAM PEMILIHAN UMUM LEGISLATIF DI KALIMANTAN TENGAH TAHUN 2019
}

\author{
Jhon Retei Alfri Sandi \\ FISIP Universitas Palangka Raya \\ Email: jhonrete@fisip.upr.ac.id
}

\begin{abstract}
Abstrak
Gereja Kalimantan Evangelis yang disingkat GKE merupakan organisasi gereja Protestan di pulau Kalimantan. Di event politik pemilu, potensi GKE sangat dilirik sebagai lumbung suara politik. Pemilu serentak legislatif dan presiden tahun 2019 khususnya oleh para calon anggota DPR RI dan DPD RI daerah pemilihan Kalimantan Tengah mendorong GKE pada sikap dan tindakan politik. Bagaimana perilaku politik GKE terhadap para calon anggota legislatif, hendak menjadi pertanyaan besar dalam penulisan ini,. Metode penelitian di gunakan kuntitatif dan kualitatif, yakni menjaring informasi/data penelitian dengan menggunakan teknik kuesioner yang disebar secara online dan wawancara mendalam. Hasil penelitian menunjukan bahwa : GKE tidak hanya terlibat mendorong jemaat mempergunakan hak politik dan berpartisipasi aktif pada kegiatan pemungutan suara, serta bersikap dan bertindak aktif mendorong jemaat melalui surat rekomondasi, mempromosikan calon legislatif dari GKE dan menindak lanjuti dengan menggerakan potensi sumberdaya GKE untuk menggalang dukungan dari jemaat.
\end{abstract}

\section{Kata Kunci: \\ Perilaku Politik, Pemilu Kalimantan Tengah, GKE}

\begin{abstract}
Kalimantan Evangelical Church abbreviated as GKE is a Protestant church organization in Kalimantan. In political election, the potential of GKE is highly regarded as political ballot storage. The concurrent election of legislative and President in 2019 especially by the candidates for the parliament in Central Kalimantan pushed GKE into political attitudes and actions. How the political behavior of the GKE towards legislative candidates would like to be a big question in this discussion. Quantitative and qualitative research method was used to collect information or research data by involving a questionnaire technique that distributed online and in-depth interviews. The result shows that the GKE is not only involved to encourage congregations to use political rights and actively participated in the voting activities, but also actively encouraging the congregations through recommendation letter, promoting legislative candidates from GKE and mobilizing the potential of GKE resources to collect supports from the congregation.
\end{abstract}




\section{Keywords: \\ Political Behavior, Central Kalimantan Election, GKE}

\section{Pendahuluan}

Tulisan ini memberikan gambaran pemikiran tentang perilaku politik organisasi gereja dalam pelaksaanaan kontestasi pemilihan umum (pemilu) legislatif. Organisasi gereja di sini dimaknai sebagai institusi yang memiliki anggota dan secara kuantitas jumlah anggota dilihat sebagai basis massa dalam nilai elektoral. Studi tentang organisasi gereja dan politik serta kaitannya dengan peran pengurus gereja dalam kancah politik, telah banyak dilakukan oleh peneliti-peneliti terdahulu, seperti yang ditulis Longgina Novadona Bayo yang melihat kontestasi tiga kekuatan besar yaitu negara, gereja dan adat dalam perubahan sosial masyarakat. Argumennya bahwa ketika kekuatan negara dan gereja melemah maka adat menjadi dominan dalam mereprsentasi perubahan sosial masyarakat. ${ }^{1}$ Begitu juga dengan Sheina Palenewen yang menjelaskan tentang bagaimana kaitan peran organisasi gereja dalam mempersiapkan warga jemaatnya untuk maju dalam pentas politik pemilu legislatif dengan melakukan pastoral. Argumen dan temuannya di lapangan menekankan bahwa gereja (pelayan gereja) terlalu fokus pelayanan pastoral sebelum kotestasi tetapi sesudah kontestasi gereja terkesan kurang memberi pelayanan bagi warga jemaat yang ikut bertarung sebagai calon legislatif 2019. ${ }^{2}$ Berangkat dari studi di atas penulis menggambarkan organsisasi gereja dengan negara/politik dalam perspektif yang berbeda, yaitu melihat dari aspek perilaku politik institusi Gereja Kristen Evangelis (GKE) dalam pentas politik.

Pemilu merupakan suatu instrumen sistem demokrasi yang berfungsi sebagai sarana rakyat memilih pemimpin untuk duduk mengisi jabatan-jabatan politik baik di Lembaga Eksekutif maupun Lembaga Legislatif. Sejak pemilu 1955 sampai pemilu 2019 yang dilaksanakan secara periodik, telah memberikan ruang politik bagi masyarakat menentukan wakil-wakilnya untuk duduk dilembaga perwakilan politik baik di DPR RI, DPD RI, DPRD Provinsi dan DPRD Kabupaten/Kota.

\footnotetext{
${ }^{1}$ Longgina Novadona Bayo,"State Neglect, Church Decline, and Ascendent Adat: The Power Contestation in Adonara, Eastern Flores" dalam Jurnal Ilmu Sosial dan Ilmu Politik, Vol. 13, No. 2 (2009), h. 149-171.

2 Sheina M.S. Palenewen,"Pendampingan Pastoral Bagi Calon-Calon Legislatif Kristen di Wilayah Bitung III". Skripsi. (Tomohon: Fak. Theologi UKI Tomohon, 2019).
} 
Secara konstitusional Undang-Undang Dasar 1945 Pasal 22 E ayat (2) menyatakan Pemilihan Umum diselenggarakan untuk memilih anggota Dewan Perwakilan Rakyat, Dewan Perwakilan Daerah, Presiden danWakil Presiden dan Dewan Perwakilan Rakyat Daerah. ${ }^{3}$ Dan setiap warga negara memiliki hak dan kewajiban yang sama di dalam hukum dan pemerintahan serta memili kihak dan kewajiban dipilih dan memilih dalam kegiatan pesta demokrasi pada pemilihan umum (pemilu) sebagaimana dinyatakan pada Pasal 27 atay (2) yakni 'Segala warganegara bersamaan kedudukannya didalamhukum dan pemerintahan dan wajib menjunjung hukum dan pemerintahan dengan tidak ada kecualinya. Pasal 28 D ayat (2) Undang-Undang Dasar 1945 selanjutnya menegaskan bahwa 'Setiap warga negara berhak memperoleh kesempatan yang sama dalam pemerintahan'. ${ }^{4}$

Setiap warga negara Indonesia yang termasuk warga gereja memiliki hak politik untuk ikut serta dalam pemilihan umum, baik 'hak memilih' sebagaimana ketentuan Undang-Undang No. 7 Tahun 2017 Pasal 198 ayat (1) dan ayat (3) tentang Pemilu untuk Pemilu Legislatif/ Presiden dan 'hak dipilih' sebagaimana ketentuan Pasal 221 untuk Calon Presiden dan Wakil Presiden, Pasal 240 untuk Pemilu Legislatif Anggota DPR, DPRD Provinsi dan DPRD Kabupaten/Kota dan Pasal 181 dan 182 untuk DewanPerwakilan Daerah Republik Indonesia (DPD RI). ${ }^{5}$ Pemilu Legislatif untuk memilih anggota DPR RI, DPRD Provinsi dan DPRD Kabupaten /Kota dan DPD RI yang dilakukan serentak bersama Pemilu Presiden/ Wakil Presiden tahun 2019 telah mendorong warga gereja, pejabat gereja dan organisasi gereja dilingkungan GKE terlibat langsung dalam kegiatan politik pemilu, baik menjadi Calon Anggota DPR RI, DPD RI, DPRD Provinsi dan DPRD Kabupaten / Kota dan menjadi 'masyarakat pemilih' disemua tingkatan dan daerah pemilihan.

Pengurus dan pimpinan gereja dilingkungan GKE terlibat pada kegiatan Pemilu didorong banyak hal, baik itu yang datang dari dalam (internal) individu atau pun di luar individu (eksternal). Secara umum, keterlibatan pengurus dan pimpinan GKE menjadi Calon Anggota Legislatif bahkan Calon Kepala/Wakil Kepala Daerah (Pilkada)

\footnotetext{
${ }^{3}$ Dewan Perwakilan Rakyat RI, "Undang-Undang Dasar Negara Republik Indonesia Tahun 1945” dalam http://www.dpr.go.id/jdih/uu1945 diakses 1 Januari 2020.

${ }^{4}$ Ibid.

${ }^{5}$ Komisi Pemilihan Umum RI, "Undang-Undang Nomor 7 Tahun 2017 tentang Pemilu" dalam https://jdih.kpu.go.id/detailuu-6c4d54564530516c4d3051253344 diakses 1 Januari 2020.
} 
karena adanya peluang dan kesempatan. Di mana pada satu sisi pengurus atau pimpinan GKE memiliki kemampuan memenuhi persyaratan pencalonan yang ditetapkan undangundang dan sisi lain mereka juga memiliki akses, jaringan basis massa, organisasi serta modalitas yang cukup.

Keberadaan organisasi GKE yang cukup membumi di wilayah Kalimantan, di mana secara organisasi telah berdiri sejak 10 April 1893 dan dikukuhkan dengan badan hukum Keputusan Gubernur Jenderal No.23 LN No.217 tanggal 24 April 1937 J.A.5/104 tanggal 17 November 1954 dan Keputusan Dirjen Bimas Kristen Protestan Departemen Agama RI No.32 tanggal 02 Pebruari 1988. Jumlah jaringan organisasi di bawah Majelis Sinode yang cukup besar yang tersebar luas di pulau Kalimantan dan luar Kalimantan yakni tingkat Resort Definitif sebanyak 92, Calon Resort sebanyak 8, Majelis Jemaat Definitif sebanyak 1.017 dan Calon Majelis Jemaat sebanyak 248 dengan jumlah kepalakeluarga 86.347 KK, jumlah jiwa sebanyak 324.801 jiwa, jumlah warga jemaat yang telah angkat side sebanyak 206.917 jiwa, serta jumlah pendeta aktif pelayanan sebanyak 653 orang. ${ }^{6}$ Banyaknya pengurus dan anggota yang ada, mungkin diyakini dapat menjadi modal para pengurus dan pimpinan GKE memenangkan kontestasi pertarungan politik dan menduduki kursi di parlemen.

Oleh karena itu, untuk menjelaskan hal di atas maka studi ini berusaha menjawab pertanyaan kunci, yakni; Benarkah keterlibatan aktif pada organisasi GKE mampu menjadi modal bagi para pengurus dan pimpinan GKE memenangkan kontestasi pemilu legislatif?. Bagaimanakah peran politik pengurus/pimpinan GKE memanfaatkan organisasi GKE meraih dukungan suara politik wargagereja?. Bagaimana peran organisasi formal GKE untuk memenangkan pengurus/pimpinan organisasi GKE pada kontestasi Pemilu Legislatif 2019 ?.

Menjadikan organisasi gereja (GKE) sebagai penggalangan suara massa atau basis massa dalam kegiatan pemilu, merupakan suatu kategori perilaku politik. Perilaku politik tidak hanya sebatas pada pemberian suara dalam pemilu saja, atau menyangkut proses pembuatan dan pelaksanaan keputusan politik, namun jauh dari itu adalah 'keseluruhan perilaku yang menyangkut persoalan politik'. ${ }^{7}$ Perilaku politik masyarakat

\footnotetext{
${ }^{6}$ Badan Pekerja Harian Majelis Sinode GKE, Almanak GKE 2019 (Banjarmasin: Sinode GKE, 2019), h. 1.

${ }^{7}$ Sudijono Sastroatmodjo, Perilaku Politik (Semarang: IKIP Semarang Press, 1995), h. 3.
} 
salah satunya juga dipengaruhi oleh agama dan keyakinan, agama dan keyakinan sangat menentukan sikap dan tindakan politik. ${ }^{8}$ Sehubungan dengan itu penulis tertarik mengkaji lebih dalam perilaku politik, pengurus/pimpinan gereja yang menjadi Calon Anggota Legislatif DPR RI dan DPD RI serta peran organisasi formal GKE seperti Majelis Sinode, Majelis Resort dan Majelis Jemaat dalam menggalang dukungan suara warga jemaat pada Pemilu Legislatif 2019.

\section{Gereja dan Negara}

Hubungan gereja dan negara merupakan sebuah hubungan yang telah lama terjalin, sejak manusia berkuasa dan menguasai manusia lain dalam sebuah ikatan organisasi yang disebut negara. Negara yang di dalamnya terdapat unsur-unsur seperti wilayah, penduduk dan pemerintah ${ }^{9}$ menempatkan gereja dan para pengikutnya menjadi bagian unsur negara itu sendiri yang bertindak sebagai warga negara.

Sebagai warga negara, orang Kristen tidak terlepas dari kehidupan berbangsa dan bernegara. Ketika orang Kristen memiliki hak dan tanggungjawab di dalam bergereja, maka orang Kristen juga harus memiliki hak dan tanggungjawab kepada negara. Negara yang merupakan agen masyarakat untuk mengatur hubungan-hubungan di dalam masyarakat agar terpelihara ketertiban masyarakat ${ }^{10}$ dan menurut Robert Mc.Iver mendefenisikan negara sebagai asosiasi yang menyelenggarakan penertiban di dalam suatu masyarakat dalam suatu wilayah, dengan berdasarkan pada satu sistem hukum yang diselenggarakan oleh suatu pemerintah yang untuk maksud tersebut diberi kekuasaan memaksa. ${ }^{11}$

Peran penting gereja dan para pengikutnya dalam mengakui eksistensi kedaulatan negara, harus dilaksanakan mengingat dalam tata kehidupan sosial masyarakat pasti akan muncul kekuatan-kekuatan kelompok yang ingin memaksakan kehendaknya, sehingga mengancam keamanan dan ketertiban masyarakat secara luas, untuknya negara harus hadir sebagai organisasi yang bertindak menyelesaikan segala macama ketegangan baik dengan cara damai maupun memaksa guna mengatur persoalan-persoalan bersama atas nama masyarakat.

\footnotetext{
${ }^{8}$ Ibid, h. 25.

${ }^{9}$ Miriam Budiardjo, dkk., Pengantar Ilmu Politik (Tangerang Selatan: Universitas Terbuka,

${ }^{10}$ Ibid, h. 1-21.

${ }^{11} \mathrm{Ibid}$, h. 1-20.
} 2014). 
Negara yang teraktualisasi dengan aktivitas Pemerintah-Rakyat yang mendiami wilayah yang menjadi yurisdiksi kewenangannya. Negara, disamping mengendalikan kekuatan yang bertentangan satu sama lainnya, negara juga mengintegrasikan kegiatan warga masyarakat kearah tercapainya tujuan-tujuan nasional. ${ }^{12}$

Menurut Andreas A. Yewangoe pemahaman mengenai hubungan gereja dan negara tidak dapat dilepaskan dari pemahaman teologis. Keduanya (Geraja - Negara) adalah alat yang dipakai Allah untuk menyatakan kehendaknya kepada manusia. ${ }^{13}$ Keduanya tidak boleh dicampuradukan, tetapi juga tidak boleh dipisahkan sama sekali. Gereja dan negara adalah dua lembaga yang dibentuk oleh Allah dan dipakai untuk menyatakan kehendakNya, di mana keduanya memiliki tugas yang sama untuk menciptakan kesejahteraan dan memiliki otoritas ultimat dari Allah.

Pada umumnya prinsip-prinsip hubungan gereja dan negara menurut Yewangoe $^{14}$ yakni; Pertama, gereja tidak boleh berdiri diatas negara; Kedua, negara tidak boleh berdiri diatas gereja; Ketiga, gereja dan negara berdiri terpisah dengan tugas masing-masing tetapi dengan tugas yang sama yaitu menciptakan kesejahteraan umum bagi umat manusia.

Menurut Calvin yang mengikuti pandangan Klaksik mengatakan bahwa gereja dan negara sama-sama ditetapkan oleh Allah tanpa terjadi subordinasi oleh satu terhadap yang lain dan tidak ada kendali dari pihak yang satu terhadap yang lainnya. Keduanya memiliki otoritas yang koordinat di bawah otoritas ultimit Allah, yang dinyatakan melalui firmanNya. ${ }^{15}$

\section{Metode Penelitian}

Penelitian ini menggunakan tipe penelitian eksploratif yakni metode yang lebih menekankan pada aspek pemahaman secara mendalam terhadap suatu masalah dari pada melihat permasalahan untuk penelitian generalisasi. Teknik analisis mendalam (indepth analysis) digunakan untuk mengkaji masalah satu per persatu berdasarkan hasil perhitungan scoring prosentase pengisian kuesioner secara online. Pendekatan

\footnotetext{
${ }^{12}$ Ibid.

13 Andreas A. Yewangoe, Tidak ada Penumpang Gelap: Warga Gereja, Warga Bangsa (Jakarta: BPK Gunung Mulia, 2009).

${ }^{14}$ Ibid, h. 186.

${ }^{15}$ H. Berkhof \& I.H. Enklaar, Sejarah Gereja (Jakarta: BPK Gunung Mulia, 1996), h. 161.
} 
penelitian yang digunakan yaitu pendekatan kuantitatif dan kualitatif atau metode campuran (mixed method). Metode ini digunakan untuk menjawab kebutuhan data penelitian, sehingga permasalahan penelitian dapat dieksplor secara tajam dengan menyanding data perhitungan scoring prosentase dan data hasil wawancara mendalam terhadap informan yang berkompeten.

\section{GKE dalam Konteks Sosial}

GKE adalah sebuah organisasi sosial kemasyarakat berbasis keagamaan Kristen yang dibentuk dalam rangka menaungi dan mewadahi pelayanan umat Kristiani di bumi Kalimantan atau Borneo. GKE adalah organisasi gereja tertua di Kalimantan yang para anggota umumnya berasal dari masyarakat Dayak yang merupakan penduduk asli pulau Kalimantan. Dimulai dengan kehadiran para misionaris atau zending Mr. Johann Heinrich Barnstein dari Badan Missi Rheinische Missionsgesellschaft zu Barmen (RMG) yang tiba di Banjarmasin pada Juni 1835 diikuti beberapa missioner lain gelombang kedua untuk menyampaikan berita anugerah penyelamatan dari Tuhan Yesus Kristus.

Masyarakat Dayak yang hidup sangat terkebelakang dan terisolir serta percaya kepada kekuatan-kekuatan roh dengan sistem kepercayaan animisme dan dinamisme, perlahan-lahan dibebaskan dari kehidupan tradisional mereka dan bergeser menuju ke peradaban kehidupan masyarakat modern yang percaya kepada Tuhan dan hidup dalam tatanan sosial kehidupan masyarakat yang lebih baik. Kehadiran para zending dan ajaran agama Kristen yang dibawa mereka di tanah Dayak berlahan-lahan menggeser peradaban masyarakat Dayak dari yang tidak mengenal Tuhan menjadi mengenal Tuhan Yesus Kristus, dan dari hidup primitif, nomaden, kayau mangayau, terisolir, miskin dan mengalami kebodohan menjadi lebih modern, menetap, beradab, berkebudayaan dan lebih sejahtera.

Sebagai penduduk asli Kalimantan Tengah (istilah yang kita kenal sekarang), masyarakat Dayak Kristen yang telah menerima Yesus Kristus sebagai Tuhan dan Juru Selamat dari pemberitaan para zending, terus berjuang memperbaiki kehidupan sosial mereka. Para missioner yang datang untuk memberitakan Kabar Keselamatan bagi masyarakat Kalimantan Tengah khususnya masyarakat suku Dayak, juga datang memberikan pengetahuan, keterampilan dengan membuka sekolah-sekolah, pusat 
pelayanan kesehatan dan kegiatan-kegiatan ekonomi agar masyarakat Dayak baik yang telah Kristen maupun belum Kristen dapat meningkat kualitas kehidupannya sehingga menjadi lebih maju, beradab, sejahtera dan mampu bersaing dengan masyarakat sukusuku lain di nusantara. Beberapa sekolah yang telah dibentuk oleh para zending seperti Sekolah Pendeta yang sekarang kita kenal dengan Sekolah Tinggi Theologia Banjarmasin, Sekolah Teknik Mandomai, Sekolah Menengah Pertanian Tumbang Lahang, Rumah Sakit atau Klinik Pusat Kesehatan Masyarakat di Barimba, di Tumbang Marikoi, di Banjarmasin dan lain-lain.

Perubahan dan pembaharuan yang digerakan oleh para missioner pada masyarakat Dayak Kristen baik dari aspek pendidikan, kesehatan, perekonomian dan lain-lain telah menempatkan masyarakat suku Dayak Kristen berperan cukup dominan dalam tata kehidupan di Kalimantan Tengah. Banyak para warga masyarakat Dayak Kristen yang berhasil menyelesaikan pendidikan baik di wilayah pulau Kalimantan maupun di luar pulau Kalimantan karena dorongan serta pencerahan para missioner lalu kembali ke tanah Dayak Kalimantan Tengah dan menjadi pemimpin dan penggerak pusat-pusat kegiatan sosial, ekonomi, politik dan pemerintahan. Menurut Usop para tokoh-tokoh Dayak Kristen bersama tokoh-tokoh masyarakat Dayak lainnya tampil dalam berbagai kegiatan sosial kemasyarakat bahkan dalam upaya perjuangan perlawanan terhadap pemerintah kolonial serta pergerakan kemerdekaan Indonesia. ${ }^{16}$

Pengetahuan dan ketrampilan yang diajarkan pada warga Kristen Dayak yang dilakukan oleh para missioner bersama dengan pemberitaan ajaran Yesus Kristus telah menempatkan para warga Kristen Dayak berperan strategis. Para tokoh Dayak ini tampil bahu membahu memperjuangkan kebebasan dan kesejahteraan masyarakat suku Dayak agar terlepas dari cengkraman penjajah kolonial, terlepas dari penguasaan antekantek kolonial serta tekanan dan penguasaan kerajaan lain yang masuk diwilayah Kalimantan Tengah seperti raja-raja banjar. Hampir semua lini kehidupan masyarakat Kalimantan Tengah, dimasuki dan melibatkan warga Dayak Kristen, yang pada tahun 1935 disatukan dan diikat dalam satu organisasi gereja yang disebut Gereja Dayak Evangelis (GDE) dan pada perkembangan berubah menjadi Gereja Kalimantan Evangelis (GKE) sebagaimana hasil persidangan pertama di Kuala Kapuas.

${ }^{16}$ Kma M. Usop, Pakat Dayak: Sejarah Integrasi dan Jatidiri Masyarakat Dayak Daerah Kalimantan Tengah (Palangka Raya: Yayasan Pendidikan dan Kebudayaan Batang Garing, 1996), h. 36. 
GKE bersama para warganya dari waktu ke waktu selalu mampu menyuarakan aspirasi dan kepentingan masyarakat dan umat. Pada tahun-tahun awal revolusi pergerakan kemerdekaan Indonesia dan tahun-tahun pembangun Kalimantan Tengah menjadi provinsi baru ke-17 dalam wilayah kekuasaan Negara Kesatuan Republik Indonesia dekade awal tahun 1957-1990, GKE berperan besar bersama pemerintah dan komponen masyarakat Kalimantan Tengah lainnya. Akan tetapi seiring dengan kemajuan dan perubahan jaman, pergantian rezim pimpinan daerah, migrasi penduduk yang sangat besar baik dari wilayah Kalimantan Selatan, pulau Jawa dan daerah lainnya karena program transmigrasi, perpindahan alamiah yang menempatkan pergeseran struktur penduduk dari yang semula dominan masyarakat Dayak menjadi berimbang dengan jumlah penduduk pendatang lainnya, telah menggeser posisi dan peran strategis masyarakat asli suku Dayak baik Kristen maupun non Kristen dalam berbagai kancah kehidupan sosial politik masyarakat Kalimantan Tengah. Perubahan ini telah berdampak pada peran dan posisi GKE sebagai organisasi Gereja Protestan tertua di Kalimantan Tengah. GKE tidak lagi menjadi organisasi utama dalam berbagai kegiatan kehidupan sosial kemasyarakat serta peranannya di mata pemerintah, karena munculnya berbagai organisasi gereja lain menjadi mitra baru pemerintah dan organisasi masyarakat lainnya.

\section{Perilaku Politik GKE}

Dalam kehidupan berpolitik masyarakat dan bernegara, setiap individu pasti terkait persoalan politik baik langsung maupun tidak langsung, baik dalam arti sempit maupun arti luas. Masyarakat sebagai kumpulan individu memiliki harapan sekaligus tujuan yang hendak diwujudkan, demikian pula masyarakat GKE dengan individuindividu di dalamnya. Pemilu Legislatif tahun 2019 menjadi arena bagi masyarakat Indonesia dari semua kalangan untuk terlibat dalam kekuasaan negara, menjadi anggota DPR RI, DPD RI dan DPRD Provinsi, Kabupaten/Kota. Pemilu menjadi media pembangunan partisipasi politik rakyat yang merupakan arena seleksi bagi rakyat untuk mendapatkan jabatan-jabatan penting dalam pemerintahan, termasuk manjadi anggota legislatif nasional DPR RI dan DPD RI.

Di lingkungan GKE, pemilu legislatif 2019 telah mendorong kegiatan dan aktivitas politik warga GKE pada proses pemilu, baik menjadi calon anggota legislatif 
DPR RI untuk memperebutkan 6 kursi dan calon anggota DPR RI untuk memperebutkan 4 kursi dan menjadi warga pendukung atau pemilih pemilu (konstituen). Berdasarkan data dari KPU, sebanyak 80 orang calon legislatif DPR RI daerah pemilihan Kalimantan Tengah terdapat 14 di antaranya berasal dari GKE. Sedangkan calon anggota DPD RI berasal dari daerah pemilihan Kalimantan Tengah pada pemilu legislatif 2019 sebanyak 21 orang dan 4 di antara warga GKE dan memiliki kedudukan dalam organisasi GKE. ${ }^{17}$

Perilaku politik terkait erat dengan sikap politik dan tindakan politik. Sikap dan tindakan politik ditunjukan dalam berbagai aktivitas-aktivitas politik organisasi dan individu-individu yang ada di dalamnya. Pada pemilu legisltaif 2019 lembaga GKE dan para anggotanya memiliki aneka sikap dan tindakan dalam memaknai pemilu dan politik, baik dari aspek kepentingan diri pribadi, organisasi, sosial kemasyarakat, etnisatas dan bangsa. GKE sebagai organisasi yang digerakan secara hirarki melalui Majelis Sinode GKE, berjenjang ke Majelis Resort, Majelis Jemaat dan warga jemaat dalam perilaku politiknya memiliki sikap dan tindakan tersendiri dalam proses pelaksanaan pemilu legislatif 2019.

\section{Sikap Politik GKE}

Sikap politik lazimnya menyangkut kesiapan untuk bereaksi terhadap objek tertentu yang bersifat politik. GKE sebagai organisasi dengan jumlah anggota yang cukup besar di Kalimantan Tengah memiliki sikap politik terhadap pelaksanaan pemilu legislatif 2019 baik menyangkut respon terhadap kewajiban dan tanggungjawab dalam pelaksanaan pemilu, juga respon dan tanggungjawab terhadap para anggotanya yang terlibat dalam kegiatan pencalonan menjadi anggota DPR RI dan DPD RI, DPRD Provinsi dan DPRD Kabupaten Kota, bahkan Presiden/Wakil Presiden pada Pemilu Presiden/Wakil Presiden 2019.

Berdasarkan analisis data responden untuk kalangan pimpinan dan pengurus GKE, terdiskripsi hampir semua responden $100 \%$ atau 6 orang setuju bahwa GKE harus mendorong secara aktif warga jemaat untuk berpartisipasi dalam kegiatan pemilu legisltaif 2019 dan pemilu lainnya. Hampir semua tingkatan majelis berjenjang dari

\footnotetext{
${ }^{17}$ Data KPU Provinsi Kalimantan Tengah Tahun 2019.
} 
tingkat majelis sinode ke jejaring tingkat di bawahnya secara pro aktif bersikap mendorong para warga jemaat untuk terlibat dan berpartisipasi aktif pada kegiatan pemilu serentak 2019. Sikap politik GKE tersebut dibangun dari pemahaman bahwa Pemerintah adalah wakil Allah di bumi dan gereja harus memberikan dukungan serta bantuan mewujudkan kedamaian dan kesejahteraan di bumi.

Sikap politik ini sangat sesuai dengan harapan warga jemaat GKE yang dapat diukur dari isian kuesioner 260 responden warga jemaat yang disebar secara online menggunakan google formulir. ${ }^{18}$ Di mana sebanyak $92,7 \%$ atau 241 responden sangat setuju agar GKE di semua pemilu mendorong secara aktif warga gereja mempergunakan hak politik secara benar dan melakukan pendidikan politik, hanya 6,5\% atau 17 responden menyatakan kurang setuju dan $0,8 \%$ yang menyatakan tidak setuju.

Sikap GKE terhadap pelaksanaan pemilu legislatif 2019 dan terhadap para kader GKE yang mencalonkan diri sebagai anggota DPR RI, DPD RI, DPRD Provinsi dan DPRD Kabupaten/Kota sangat terbuka, mengingat kegiatan dan proses-proses pemilu serta proses pencalonan anggota legislatif tingkat pusat dan daerah tidak terkait langsung dengan GKE. GKE dan warganya hanya sebagai bagian dari unsur masyarakat yang menjadi bagian komponen atas kewajiban dan tanggungjawab sebagai warga negara yang baik sebagaimana diperintahkan di dalam Undang-Undang Dasar 1945 dan Undang-Undang No.7 Tahun 2017 tentang Pemilihan Umum.

Para warga GKE yang mencalonkan diri menjadi caleg DPR RI, DPD RI, DPRD Provinsi dan DPRD Kabupaten/Kota harus melalui mekanisme yang diatur dari partai politik yang menjadi pilihannya. Sehingga secara struktural dan fungsional peranan GKE pada proses kegiatan pencalonan anggota legislatif sangat kecil atau hampir tidak ada, terkecuali untuk calon anggota DPD RI yang membutuhkan pernyataan dukungan 2.000 anggota masyarakat pemilih yang dilampirkan dengan bukti kartu tanda penduduk (KTP) serta pengisian blangko pernyataan dukungan yang akan diverifikasi faktual oleh KPUD sebelum waktu penetapan dari bakal calon menjadi calon tetap anggota DPD RI. GKE secara umum tidak membatasi langsung warganya untuk menjadi caleg karena

\footnotetext{
${ }^{18}$ Daftar isian dapat dilihat pada link https://forms.gle/6rw1aUAxBPZEvS9Q9.
} 
memang bukan domain langsung GKE seperti diungkapkan salah satu unsur pimpinan GKE sebagai berikut :

Majelis sinode GKE dan semua tingkatan organisasi dibawahnya tidak pernah membatasi warga GKE menjadi caleg dalam Pemilu Legislatif 2019, karena itu merupakan hak dari semua warga negara yang dijamin dalam konstitusi. Proses pencalonan menjadi caleg adalah proses dari masing-masing internal partai politik. GKE tidak bersentuhan langsung dengan proses tersebut, itu menjadi kewenangan dan hak politik partai politik dan para kadernya. GKE sangat menyambut baik bila banyak warga GKE yang terjun dan menjadi caleg di kegiatan pemilu legislatif. Terkait dengan dukungan politik kepada para caleg dari kalangan GKE diserahkan sepenuhnya kepada warga GKE sendiri. ${ }^{19}$

Sikap politik GKE secara formal atas para calon anggota legislatif DPR RI, DPD RI dan lainnya bersifat sama dan seragam. Para caleg yang juga sebagai warga GKE memiliki kebebasan mengikuti kegiatan-kegiatan kegerejawian GKE. Para caleg dapat hadir di manapun kegiatan-kegiatan yang dilakukan GKE sepanjang terbuka bagi warga jemaat. Namun para caleg hadir sebatas kapasitasnya menjadi warga jemaat, terkecuali caleg tersebut memiliki tugas khusus di kepengurusan gereja atau di kepanitiaan gereja sehingga ia memiliki peranan lebih terkait dengan kegiatan yang ditangani dan dilaksanakan, bukan untuk melakukan sosialisasi untuk kepentingan politiknya.

Keberhasilan warga GKE duduk di lembaga legislatif atau eksekutif diharapkan akan dapat memperhatikan kepentingan serta aspirasi warga GKE di parlemen dan pemerintahan, sehingga kebijakan-kebijakan yang dibuat oleh negara atau pemerintah dapat memperhatikan kepentingan dan kebutuhan warga Kristiani umumnya dan warga GKE khususnya seperti menyangkut proporsionalitas bantuan-bantuan keagamaan pemerintah, perlindungan terhadap hak dan kewajiban dalam beragama dan melaksanakan tata keagamaannya, dan lain-lain. Seperti diungkapkan oleh salah satu caleg DPR RI sebagai berikut :

GKE harus memberikan dukungan secara penuh kepada warga GKE yang mencalonkan diri sebagai anggota legislatif baik tingkat pusat maupun tingkat daerah.GKE harus bertindak secara nyata dalam memberikan dukungannya. Karena keberhasilan caleg dari kalangan GKE pada lembaga legislatif, akan menjadi keberhasilan GKE juga. Dengan adanya warga GKE yang menjadi

\footnotetext{
${ }^{19}$ SFL, Pimpinan GKE, wawancara, 26 Oktober 2019.
} 
anggota DPR RI, DPD RI, DPRD Provinsi dan DPRD Kabupaten/Kota diharapkan dapat mengakomodasi kepentingan warga GKE khususnya dan umat Kristiani umumnya dan dapat menunjukan eksistensi GKE ditengah-tengah masyarakat bangsa. ${ }^{20}$

GKE di semua tingkatannya sangat cukup hati-hati agar organisasi GKE tidak terjebak pada domain politik praktis. Namun karena organisasi GKE adalah organisasi yang sangat dinamis dan yang terdiri dari warga gereja dengan berbagai latar belakang sosial, ekonomi, budaya, etnik bahkan ideologi politik, termasuk para pengurus dan pimpinan GKE, maka tidak bisa terhindarkan pada dimensi dan ruang waktu tertentu pasti terdapat oknum-oknum yang akan memanfaatkan dan berupaya mendapatkan manfaat dari keterlibatannya pada organisasi GKE untuk kepentingan diri pribadi, kelompok atau organisasi.

Pada pemilu 2019, Majelis Sinode berupaya menggerakan organisasi GKE untuk mengarahkan pilihan politik warga jemaat ke pasangan yang didukung. Melalui jejaring ini organisasi GKE digerakan kekuatan unsur GKE di tingkat resort, jemaat, pendeta, penatua dan diakon secara hirarkis. Kontestasi pemilu legislatif 2019 terdapat beberapa calon yang berasal dari kalangan GKE. Untuk calon anggota DPR RI dari 80 orang terdapat 14 anggota GKE dan calon anggota DPD RI dari 21 orang terdapat 4 orang anggota GKE.

Sikap politik majelis sinode GKE ini cukup unik karena pada satu sisi memberikan kebebasan kepada masing-masing warga GKE untuk ikut dalam kegiatan politik pemilu baik menjadi calon anggota legislatif dan calon anggota DPD RI, tetapi sisi lain dalam konteks kontestasi DPD RI, majelis sinode bersikap mendukung kepada salah satu kandidat caleg DPD RI secara formal.

\section{Tindakan Politik GKE}

Tindakan politik lazimnya menyangkut pilihan politik dari hasil olahan penglihatan, pemahaman dan penghayatan atas suatu obyek politik dari individu, kelompok atau institusi. Tindakan politik GKE terhadap kegiatan pemilihan umum legislatif tahun 2019 terhadap calon anggota legislatif DPR RI dan DPD RI dapat ditelaah berdasarkan aktivitas-aktivitas formal dan non-formal, aktivitas yang

\footnotetext{
${ }^{20}$ SH, Caleg DPR RI, wawancara, 26 Oktober 2019.
} 
dinyatakan secara terbuka dan melembaga. Aktivitas yang dilakukan secara tersembunyi diluar koridor kelaziman standar operasional prosedur (SOP) organisasi.

Berdasarkan wawancara penulis dengan para informan yang menjadi caleg DPR RI dari warga GKE, bahwa secara formal pada kontestasi pemilihan umum anggota DPR RI daerah pemilihan Kalimantan Tengah, GKE bertindak netral terhadap para caleg. Maksudnya Tidak ada rekomendasi atau surat dukungan resmi yang dibuat oleh Majelis Sinode GKE terhadap beberapa atau salah satu caleg. Para caleg diberi keleluasaan melakukan kampanye bagi dirinya dilingkungan gereja, melakukan sosialisasi dan menyampaikan visi dan misi secara non-formal berdasarkan kapasitas relasi hubungan non-formalnya dengan para warga jemaat. Hampir tidak ada caleg DPR RI yang diberi kesempatan secara khusus melakukan aktivitas-aktivitas politik secara formal dan terbuka pada kegiatan-kegiatan kegerejawiaan terkecuali di luar sepengetahuan majelis dan ruang yang diberi karena kapasitas jabatan di organisasi gerejawi sebagaimana pernyataan informan di bawah ini :

Untuk kegiatan pemilu legislatif DPR RI, majelis sinode GKE dan semua tingkatan organisasi di bawahnya berupaya bertindak netral. Tidak ada surat dukungan resmi atau rekomendasi kepada semua caleg yang berasal dari GKE. Warga GKE yang mencaleg diberi kesempatan yang sama untuk memanfaatkan potensi sumberdaya GKE: melakukan sosialisasi, komunikasi dan menjalin relasi kepada warga GKE guna memperoleh dukungan suara sebanyak-banyak. Memang para celeg GKE tidak diberi ruang secara formal beraktivitas politik di kegiatan-kegiatan GKE, karena rumah ibadah dan kelembagaan keagamaan tidak diperkenankan melakukan kegiatan politik praktis sebagaimana ketentuan peraturan perundang-undangan.Namun secara non formal GKE memberi ruang kepada para caleg di lingkungan GKE untuk mensosialisasikan dirinya secara non formal kepada para warga GKE dengan pendekatan kekeluargaan.GKE sangat menyambut baik bila warga GKE ingin memilih para caleg yang ada dilingkungan GKE sendiri, karena keberhasilan caleg GKE juga keberhasilan GKE secara menyeluruh.Jika ada struktur organisasi GKE dibawah majelis bertindak memberikan dukungan secara resmi, itu diluar sepengetahuan pengurus di tingkat sinode. ${ }^{21}$

Netralitas kelembagaan GKE ini harus dilakukan karena secara umum di dalam organinasi GKE memiliki pemilih yang plural. Karena itu meskipun ada beberapa caleg DPR RI yang memiliki kedudukan cukup tinggi di organisasi majelis sinode GKE

\footnotetext{
${ }^{21}$ AN, Informan Bukan Pejabat Tinggi GKE, wawancara, 26 Oktober 2019.
} 
seperti Dr.Ir. Willy M. Yosep,MM yang merupakan salah satu unsur Ketua Majelis Sinode GKE atau Pdt. Fristio,S.Th.,S.Sos, sebagai salah satu unsur anggota Majelis Sinode GKE, namun GKE harus secara berhati-hati memberikan dukungan.

Pada kontestasi caleg DPR RI daerah pemilihan Kalimantan Tengah, upaya mensosialisasikan para petinggi organisasi GKE dilakukan secara terselubung seperti menyelipkan perkenalan dan posisi keikutsertaan para caleg pejabat gerejawi ini oleh tuan rumah atau liturgos/pembawa acara di ibadah rumah tangga pada kediaman salah satu caleg tersebut dan menyebutkan dalam doa safaat yang dibawakan pendeta atau pimpinan kebaktian. Para pejabat petinggi GKE ini, karena status dan jabatannnya diberi ruang tampil pada posisi dominan, sehingga disadari atau tidak menjadi panggung tersembunyi untuk sosialisasi seperti diungkapkan salah satu informan yang bukan pejabat petinggi GKE yakni :

Pada kontestasi kursi DPR RI, majelis sinode GKE relatif bertindak sedikit netral. Meskipun dari banyak aspek beberapa tindakan terkesan lebih banyak membuka peluang bagi para pejabat tinggi GKE yang menjadi caleg untuk mensosialisasikan diri seperti pada ibadah keluarga disalah satu kediaman caleg yang dihadiri banyak warga jemaat serta para tokoh. Pembawa acara atau unsur yang mewakili organisasi GKE atau pendeta/petugas doa safaat cenderung memberikan penekanan lebih pada caleg tersebut dan menyampaikan hajatan serta harapan caleg. ${ }^{22}$

Tindakan politik GKE pada konteks ini lebih menekankan atau mengarahkan para caleg untuk beriman kepada Tuhan Yesus Kristus. Secara Imani GKE melalui Majelis sinode/resort/jemaat memberikan pengembalaan dan penguatan kepada para caleg DPR RI dan DPD RI dengan bentuk mendoakan para caleg dalam doa safaat di mimbar atau dikegiatan kebaktian-kebaktian keluarga/kategorial/kebaktian khusus. Para pendeta atau petugas biasanya menyebut nama caleg satu persatu atau mendoakan secara umum agar mereka berhasil mewujudkan harapan dan keinginan mereka dan Tuhan memberkatinya seperti diungkapkan salah seorang pendeta pejabat GKE yang menjadi informan:

\footnotetext{
${ }^{22}$ JHR, Informan Bukan Pejabat Tinggi GKE, wawancara, 24 Oktober 2019.
} 
Secara umum GKE memberikan dukungan politik pada para caleg DPR RI dan DPD RI pada pemilu legislatif 2019 dengan cara mendoakan secara safaat disetiap ibadah minggu, ibadah kategorial dan ibadah khusus agar para caleg warga GKE dapat berhasil pada kontetasi pemilu legislatif 2019. Gereja memberi dukungan secara Imani sehingga mereka memiliki keyakinan dan kepercayaan diri yang tinggi kepada Tuhan, karena Tuhanlah yang akan menggenapi dan mewujudkan harapan mereka. Penyerahan diri kepada Tuhan diserta tindakan-tindakan nyata harus dilakukan. Ora et Labora. ${ }^{23}$

Para pendeta juga bertindak memberikan penguatan melalui berbagai pelayanan kerohanian dalam bentuk penyampaian firman Tuhan dan kunjungan doa baik diminta maupun inisiatif ke keluarga rumah tangga para caleg agar tetap terus bersemangat, bekerja dan berusaha keras serta memasrahkan diri kepada Tuhan atas hasil yang ditetapkan-Nya. Berhasil atau tidak menjadi caleg DPR RI dan DPD RI itu adalah keputusan mutlak Tuhan. Jika caleg belum berhasil menjadi anggota legislatif di DPR RI dan DPD RI tidak lah harus berputus asa dan stres, tetapi menjadi pemicu serta semangat untuk berjuang 5 tahun mendatang seperti diungkapkan oleh seorang pendeta yakni:

Pendeta itu memiliki tugas melakukan pengembalaan Iman, memberikan pengutan dan penghiburan dengan firman Tuhan yang hidup.Karena itu pendeta harus bertindak sebagai konselor membimbing para anggota jemaat (caleg) untuk bisa memahami dan menerima keputusan serta kehendak Tuhan.Pendeta harus memberi pengajaran kepada warga jemaat untuk selalu bekerja keras, berjuang dengan sepenuh hati dan menyerahkan hasilnya kepada Tuhan Yesus Kristus yang hidup.Jika jemaat (caleg) mengalami kegagalan, kegagalan juga merupakan rencana Tuhan yang harus disyukuri dan jika para caleg berhasil dalam cita-citanya, keberhasilan itu sendiri merupakan pemberian Tuhan. ${ }^{24}$

Dalam kegiatan tersebut pendeta biasanya didamping unsur Badan Pekerja Harian (BPH) majelis jemaat, penetua dan diakon. Kegiatan-kegiatan tersebut biasanya dilakukan dikebaktian-kebaktian baik rumah tangga, kategorial, kebaktian minggu dan kebaktian khusus tersebut.

Berbeda dalam kontestasi caleg DPD RI daerah pemilihan Kalimantan Tengah yang menempatkan 4 orang warga GKE menjadi peserta kontestasi, tindakan GKE

\footnotetext{
${ }^{23}$ HTP, Pendeta Pejabat GKE, wawancara, 24 Oktober 2019.

${ }^{24}$ TC, Pendeta GKE, wawancara, 24 Oktober 2019.
} 
selaku institusi relatif berbeda dengan kontestasi DPR RI. Di kontestasi DPD RI majelis sinode secara formal dan non-formal memberikan dukungan langsung kepada salah satu caleg DPD RI nomor urut 39 atas nama Pdt. Dr. Simpun F. Lion, M.Th yang merupakan unsur Wakil Ketua BPH Majelis Sinode GKE Banjarmasin dengan bentuk surat rekomendasi. Rekomendasi dikeluarkan pimpinan BPH Majelis Sinode GKE yang ditandatangani oleh Sekretaris BPH Majelis Sinode GKE Pdt. John Asihua, M.Th tanggal 10 September 2018. Berikut surat rekomendasi tersebut.
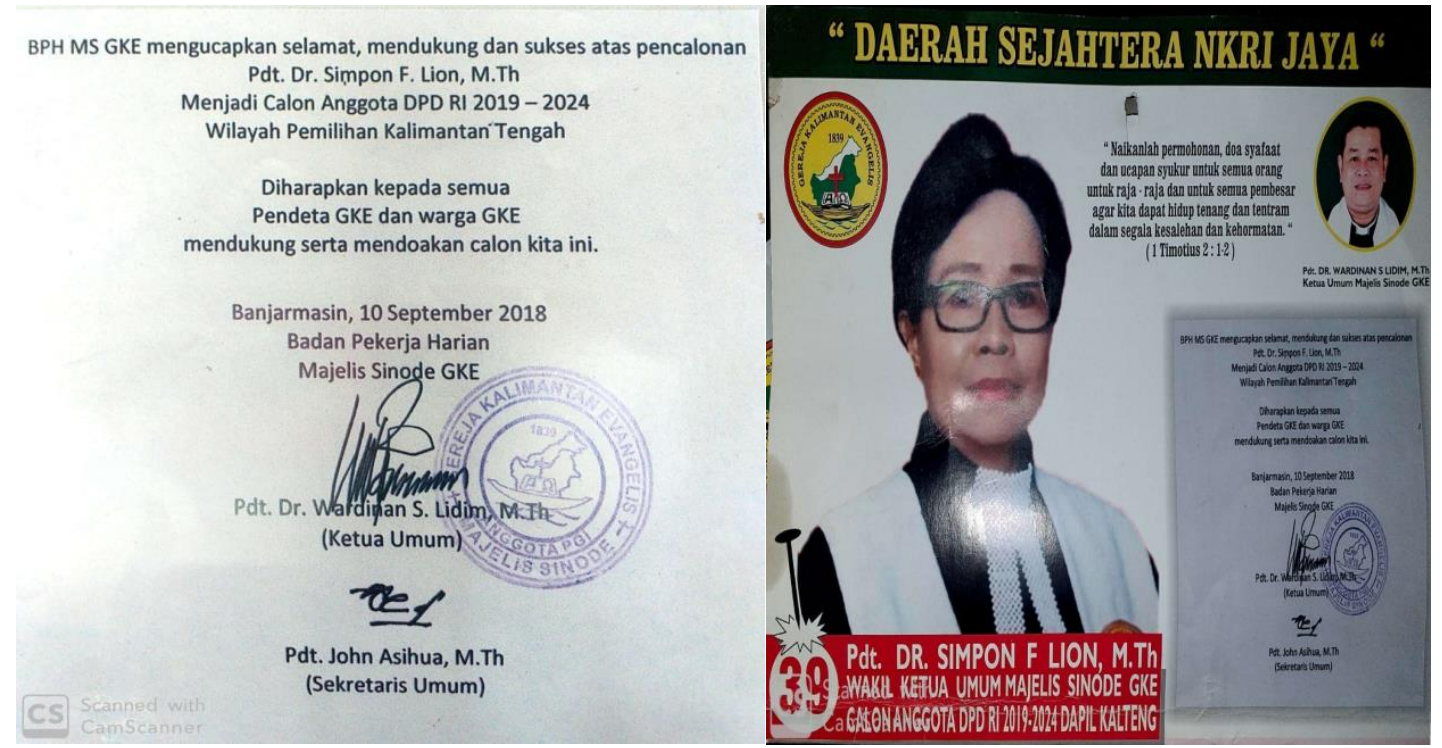

Gambar Rekomendasi Dukungan Sinode GKE

Pandangan para pimpinan GKE khususnya majelis sinode GKE, rekomendasi itu dinilai sebagai tindakan solutif guna memainkan peranan GKE dan para anggota di kancah kebijakan negara atau daerah, di mana dari 6 orang responden mewakili unsur pimpinan GKE di tingkat sinode dan 3 respoden tingkat resort atau 50\% menyatakan sangat setuju, sedangkan yang menyatakan tidak setuju sebanyak 1 responden atau $16,7 \%$ dan kurang setuju sebanyak 2 responden atau 33,3\%. Rekomendasi ini dijadikan dasar untuk menggerakan dan mengarahkan potensi GKE dalam memberikan dukungan. Melalui rekomendasi ini diharapkan struktur organisasi GKE dari tingkat atas sampai ke tingkat jemaat dengan jejaringnya memberikan dukungan baik itu tenaga, akses atas sumber-sumber daya GKE lain. Meski tindakan Majelis Sinode GKE memberikan rekomendasi kepada salah satu peserta kontestasi caleg DPD RI menuai opini pro dan 
kontra. Ada pihak yang mendukung dan ada juga yang tidak sepakat berdasarkan pada hasil jawaban dan respons dari jemaat.

GKE hanya bagian dari potensi basis massa para caleg DPR RI dan DPD RI. Selain warga GKE para caleg juga memiliki basis massa lain yang cukup berpotensi menghantarkan mereka ke gedung Senayan Jakarta. Majelis Sinode GKE dan caleg yang direkomendasikan memiliki harapan agar warga GKE dapat memberikan dukungan suaranya dengan rekomendasi yang telah ditetapkan, seperti pendeta, penetua, diakon, BPH Majelis Resort dan BPH Majelis jemaat.

Kondisi seperti ini yang menempatkan beberapa kelompok masyarakat dan pemimpin majelis GKE baik tingkat sinode, resort dan jemaat yang menerima bahwa GKE harus memperjuangkan para anggotanya yang terlibat dalam pentas politik bahkan pada kehidupan sosial, ekonomi, budaya dan kemasyarakatan diharapkan mampu tampil dalam kancah kehidupan masyarakat Kalimantan Tengah, di mana GKE suka tidak suka harus menjadi salah satu pioner dalam proses perjuangan itu. Bagi GKE termasuk pimpinan majelis memandang penting peran GKE dalam pentas politik, agar eksistensi GKE dan warganya dapat tetap eksis di tengah pembangunan yang dilaksanakan di Kalimantan Tengah. Manakala GKE dengan berbagai potensi tidak mampu mengambil peran menopang warga jemaat dan para pengurus tampil dalam berbagai dimensi kehidupan sosial kemasyarakat Kalimantan Tengah, maka GKE akan semakin ditinggalkan dan tidak diperhitungkan baik oleh Pemerintah juga masyarakat dan anggotanya. Dari warga jemaat GKE sendiri memandang bahwa GKE sebagai sebuah institusi gereja memberikan rekomendasi kepada pengurus/pejabat GKE, 52\% menjawab sangat setuju dan 28,5\% menjawab kurang setuju serta $18,3 \%$ menjawab tidak setuju.

Sikap dan tindakan proaktif melalui penerbitan rekomendasi dukungan politik kepada salah satu caleg DPD RI nomor urut 39 secara resmi di tingkat majelis sinode dan upaya menindaklanjuti, memberikan dukungan dan menggerakkan sumber daya GKE untuk memenangkan caleg yang direkomendasikan tentu menuai kritikan dan dukungan. Namun GKE pun harus realistis melihat perubahan-perubahan situasi sosial politik bangsa hari ini yang mempengaruhi jalannnya kehidupan masyarakat dengan berbagai aturan(regulasi) atas kebijakan sistem sosial, sistem politik, sistem ekonomi, sistem budaya dan sistem informasi serta komunikasi di era revolusi industri 4.0 dan 
revolusi peradaban masyarakat menuju era masyarakat 5.0, termasuk kondisi dinamika kehidupan sosial politik daerah yang tidak lagi menempatkan para tokoh-tokoh GKE yang dulu dominan duduk dalam jabatan politik, pemerintahan dan berkuasa serta monopli atas sumber-sumberdaya ekonomi, sosial dan budaya.

GKE harus berani memainkan peranan sebagai organisasi sosial kemsyarakat berbasis umat untuk mendapat tempat dan pengaruh terhadap masyarakat, Pemerintah dan mempertanggungjawab kepada Tuhan. Aktivitas pengelolaan sumber daya GKE oleh peran individu dan pengurus sebagai aktor yang menentukan kebijakan-kebijakan strategis GKE dalam kegiatan politik, harus terkelola dengan baik, terbuka dan bertanggungjawab. Aktivitas tersebut termanifestasi oleh perilaku aktor-aktor baik pimpinan majelis sinode, resort, jemaat, pendeta, panatua, diakon. Benarlah dikatakan Firman Noor bahwa individu atau aktor politik adalah elemen yang sesungguhnya menentukan kondisi atau kualitas kehidupan politik daripada lembaga-lembaga politik, ${ }^{25}$ termasuk lembaga GKE.

Beberapa kelompok majelis dan pimpinan GKE juga memiliki pemikiran untuk tetap terus melaksanakan kebijakan rekomendasi, meskipun rekomendasi yang diberikan pada caleg nomor urut 39 DPD RI kurang efektif dilaksanakan oleh seluruh komponen GKE. Di mana 50\% responden menyatakan sangat setuju agar GKE sebagai organisasi tetap melaksanakan kebijakan rekomendasi di waktu mendatang dan $15,7 \%$ menyatakan kurang setuju serta 33,3\% menyatak tidak setuju. Kebijakan ini sangat rasional mengingat latar belakang kondisi GKE di era ini, peran pengalaman historis GKE di masa masa pemerintah kolonial, masa perjuangan kemerdekaan, masa revolusi kemerdekaan dan bahkan masa awal perjuangan pembentukan Provinsi Kalimantan Tengah sebelum tahun 1957 dan mengisi pembangunan pada saat Provinsi Kalimantan Tengah telah berdiri tahun 1957 sampai dengan saat ini. Karena itu GKE harus eksis, GKE harus hadir dan tetap berperan dalam kehidupan sosial, politik, ekonomi dan kemasyarakat di Kalimantan Tengah karena organisasi GKE adalah organisasi tertua dan terbesar di Kalimantan Tengah sampai dengan saat ini.

${ }^{25}$ Firman Noor, "Perilaku Politik Pragmatis Dalam Kehidupan Politik Kontemporer: Kajian Atas Menyurutnya Peran Ideologis di Era Reformasi” dalam Jurnal Masyarakat Indonesia, Vol. 40, No. 1 (2014), h. 57-74. 
Dengan pedulinya GKE pada kegiatan-kegiatan khususnya dalam mendorong kesadaran warga jemaat mempergunakan hak-hak politik serta kesempatan-kesempatan berpartisipasi pada jabatan-jabatan politik negara, maka GKE telah melaksanakan perintah dan amanat Allah untuk mendukung penguasa atau pemerintah yang berkuasa yang menjadi wakil Allah di bumi guna menciptakan kesejahteraan bagi segenap makhluk ciptaan-Nya. GKE sebagai gereja merupakan bagian dari masyarakat yang diharuskan tunduk kepada hukum dan perundang-undang yang ada dalam masyarakat, sekalipun secara teologis hukum tertinggi yang harus diikuti gereja adalah apa yang terdapat dalam Alkitab. Hasil isian kuesioner yang dilakukan pada penelitian memberikan indikasi bahwa warga GKE tidak alergi politik dan tidak menentang secara frontal kebijakan majelis GKE yang bersifat politik, yang ditunjukan dengan pernyataan kesetujuan 92,7\% warga GKE yang menjadi responden agar gereja mendorong secara aktif warganya untuk mempergunakan hak-hak politik secara benar dan melakukan pendidikan politik dan hanya $6,5 \%$ yang menyatakan tidak setuju.

Secara Alkitabiah berdasarkan pendapat Eddy Kristiyanto yang mengatakan bahwa orang Kristen perlu untuk bersikap politis seperti halnya Yesus sendiri yang bersikap politis. ${ }^{26}$ Di mana dalam keterlibatan-Nya dengan dunia dalam sejarah manusia, Allah yang menjelma dalam diri Yesus tidak bersikap netral, melainkan melakukan suatu affirmative action yang nyata, dengan memihak manusia yang lemah dan berdosa, agar mereka diselamatkan melalui penebusan. Pilihan tersebut menyangkut nasib orang banyak yang hendak dibela, sehingga dengan jelas dapat dinyatakan bahwa Allah itu politis.

Politik dalam arti sebagai upaya-upaya untuk memperoleh kekuasaan (power, macht). Ada perjuangan memperoleh kekuasaan (machtstrijd). Kekuasaan bukanlah sesuatu yang buruk, asal saja dipergunakan untuk kemaslahatan bersama. Kekuasaan bukanlah tujuan pada dirinya, melainkan sarana untuk menghasilkan kebaikan bagi sebanyak mungkin orang. Rasul Paulus kepada jemaat di kota Roma menyatakan untuk taat kepada pemerintah sebagai suatu sikap politik. Kekuasaan yang terwujud dalam bentuk pemerintah bukanlah sesuatu yang jahat. Seperti yang di sampaikan oleh Palenewen dalam pemilu legislatif di Kota Bitung tahun 2014 tergambar adanya peran

${ }^{26}$ Eddy Kristiyanto, Sakramen Politik: Mempertanggungjawabkan Memoria (Yogyakarta: Lamalera, 2008). 
pemuka-pemuka agama atau para majelis pimpinan gereja menjadi jembatan penghubung antara kandidat dan massa untuk membangun hubungan elektoral. ${ }^{27}$

Tindakan politik GKE sebaiknya murni karena kepentingan organisasi dan kepentingan warga jemaat secara menyeluruh serta kepentingan gereja dalam menaksanakan suara kenabiannya. Menurut Yewangoe, dalam rangka keterlibatan gereja atau orang Kristen dalam dunia politik praktis, gereja atau orang Kristen harus memiliki prinsip-prinsip yang perlu dipegang agar supaya tidak terlena dalam kepentingan pribadi atau golongan tertentu. ${ }^{28}$ Prinsip-prinsip yang harus dikembangkan melingkupi, yakni; Pertama, kekuasaan yang dimiliki adalah kekuasaan yang melayani, bukan kekuasaan demi kekuasaan; Kedua, yang diperjuangkan adalah kesejahteraan bersama, bukan sekedar kesejahteraan sendiri yang pada akhirnya hanya akan menimbulkan salah paham di dalam masyarakat; Ketiga, dalam penyelenggaraan kekuasaan, mestinya etika dan moral kekuasaan dikedepankan. Perlu ada keseimbangan antara kekuasaan (power), keadilan (justice), dan kasih (love); Keempat, dengarkanlah selalu suara hati yang benar. Kompromi politik mungkin tidak terhindarkan tapi ada batasnya. Apabila kompromi-kompromi itu telah menyentuh hal yang paling prinsip dalam iman Kristen, maka "adalah lebih baik taat kepada Allah ketimbang kepada manusia" (Kis. 5:29); Kelima, gereja tidak boleh berhenti menjalankan fungsi atau pelayanan pastoralnya.

Selanjutnya Zakharia J. Ngelow menegaskan bahwa dalam pelayanan politik gereja, bukan terutama supaya orang-orang Kristen berkuasa di berbagai posisi penting untuk memuluskan kepentingan orang Kristen atau kepentingan gereja, melainkan supaya orang-orang yang baik, profesional dan berintegritas, dari berbagai latar belakang agama, Kristen atau bukan Kristen, bersama-sama melayani kepentingan seluruh masyarakat tanpa membeda-bedakan. ${ }^{29}$ Politik Kristen bukan politik kekuasaan dan kepentingan, melainkan politik pelayanan dan keadilan bagi seluruh warga masyarakat bangsa kita.

27 Jovano D. O. Palenewen, "Penerapan Patronase dalam Kemenangan Partai Keadilan dan Persatuan Indonesia pada Pemilu Legislatif Kota Bitung Tahun 2009”. Tesis. (Yogyakarta: Universitas Gadjah Mada, 2014).

${ }^{28}$ Andreas A. Yewangoe, Loc. Cit.

${ }^{29}$ Zakaria J. Ngelow,'Turut Membina Indonesia Sebagai Rumah Bersama-Peran Gereja Dalam Politik Di Indonesia” dalam Jurnal Jaffray, Vol. 12, No. 2 (2014), h. 213-234. 
Bagi kalangan lain meyatakan bahwa Gereja bukan organisasi politik yang mengarahkan warganya untuk menjatuhkan pilihan politik kepada oknum tertentu dan itu bentuk penyelewengan dan kekeliruan yang dilakukan oleh gereja dengan alasan untuk berlindung kepada penguasa atau kepentingan lain. Menurutnya bila gereja terlibat politik praktis, akibatnya bisa sangat buruk. Bahkan tak jarang terjadi ada warga gereja yang sampai menjual suaranya kepada tokoh politik tertentu untuk pembangunan gedung gereja. Hal ini termasuk money politics dan secara teologis merupakan dosa. Dengan harapan pandangan tersebut bisa dicegah dengan tindakan politik gereja berdasar pada nilai Kristen yang membawa suatu perubahan yang baik dalam sistem politik.

Berdasarkan data statistik anggota GKE sebagaimana dipaparkan pada gambaran umum tentang potensi GKE, jumlah jiwa GKE yang melebihi $336.313^{30}$ dari total penduduk Kalimantan Tengah tahun 2017 sebanyak 2.605.274 (Kalteng dalam angka 2018), jika terkelola secara efektif minimal akan dapat mendudukan 2 warga GKE di kursi DPD RI atau kursi DPR RI. Akan tetapi realitasnya warga GKE yang berhasil melenggang ke kursi gedung Senayan Jakarta hanya 2 orang caleg anggota DPR RI yakni Dr. Ir. Willy M. Yosep, MM. dari PDIP, Eri Egahny,SH dari Nasdem dan 1 caleg anggota DPD RI Dr.Agustin Teras Narang,SH yang tidak mendapat dukungan langsung atau resmi dari majelis sinode GKE namun memiliki basis massa kuat baik di GKE sendiri maupun masyarakat Kalimantan Tengah karena rekam jejak dan keberhasilan memimpin Kalimantan Tengah sebagai Gubernur Kalimantan Tengah periode 20052010 dan periode 2010-2015 dengan perolehan suara 349.351 hampir melebihi total suara anggota GKE.

Rekomendasi Majelis Sinode GKE sendiri kepada Wakil Ketua Majelis Sinode GKE Pdt.Dr. Simpun F.Lion caleg DPD RI nomor urut 39 pada kenyataanya tidaklah sia-sia. Skoring angka 50\% setuju dengan kebijakan rekomendasi dan $50 \%$ menyatakan kurang setuju dari isian responden dengan kebijakan rekomendasi juga berdampak pada kontribusi perolehan suara yang menunjukan hasil yang cukup luar biasa. Di mana berdasarkan data penetapan hasil KPU untuk caleg DPD RI daerah pemilihan Kalimantan Tengah Pdt. Dr. Simpun F. Lion berhasil mengumpulkan suara sebanyak

\footnotetext{
${ }^{30}$ Sumber Nast Almanak GKE tahun 2018.
} 
57.869 dan menduduki posisi nomor urut cadangan 6 dari 4 kursi yang telah diisi oleh caleg terpilih DPD RI. Perolehan suara ini cukup luar biasa di tengah-tengah kompetisi pemilu legislatif yang cukup rumit, kompleks dan berbiaya tinggi dimana Pdt. Dr. Simpun F. Lion yang merupakan pendatang baru di dunia politik harus mampu berjuang menghadapi para kandidat caleg DPD RI yang rata-rata punya pengalaman rekam jejak politik tinggi baik sebagai mantan senator, gubernur, anggota DPRD provinsi, kabupaten/kota, pejabat birokrat, pengusaha dan para politikus. Perolehan suara 57.869 dan menduduki rangking 6 merupakan perolehan suara maksimal yang telah diraih dan dapat menjadi indikator betapa sebagian warga GKE masih tunduk dan taat pada garis kebijakan organisasi GKE.

Belajar dari pengalaman politik pemilu legislatif 2019 ini, GKE harus menata diri dalam menghadapi event-event politik nasional dan daerah agar dapat berkontribusi secara optimal. GKE harus berhati-hati menentukan sikap dan tindakan politik. Sikap dan tindakan politik gereja harus teguh berorientasi kepada kemurnian pelayanan dan hormat bagi nama Tuhan Yesus Kristus, bukan untuk kepentingan kelompok atau pimpinan. Kesalahan GKE dalam pengambilan keputusan-keputusan strategis GKE akan berdampak pada keutuhan organisasi GKE itu sendiri. Karena itu kapasitas managerial pejabat dan pemimpin GKE serta kemurnian pelayanan dalam menata kelola orgnisasi GKE harus lebih ditingkatkan. Organisasi GKE harus mampu melakukan komunikasi, koordinasi dan sinkronisasi dengan semua komponen GKE yang memiliki potensi.

\section{Kesimpulan}

Pemilu legislatif 2019 berimplikasi pada kontestasi antar partai politik peserta pemilu dan secara khusus calon anggota legislatif DPR RI dan DPD RI. Organisasi gereja yang menjadi induk wadah keumatan dari para calon tersebut dalam hal ini GKE dengan jejaring basis masa di bawahnya ingin mengambil peran untuk berpartisipasi dalam politik. GKE sebagai organisasi gereja Protestan tertua di Kalimantan Tengah memiliki beberapa warga jemaat yang menjadi calon anggota legislatif DPR RI dan DPD RI daerah pemilihan Kalimantan Tengah. GKE tidak hanya terlibat mendorong warga jemaat menggunakan hak politik untuk memilih dalam pemungutan suara, tetapi juga GKE bersikap dan bertindak aktif mendorong warga jemaat untuk tampil dalam 
perhelatan politik serta memberi dukungan kepada calon dari GKE. Hal ini nampak dalam pemilihan DPD RI daerah pemilihan Kalimantan Tengah melalui kebijakan penerbitan surat rekomondasi kepada salah satu calon anggota legislatif DPD RI dan menindak lanjuti dengan menggerakan potensi sumber daya GKE untuk menggalang dukungan dari warga jemaat.

Perilaku politik GKE untuk mengambil peran dalam pentas politik di Kalimantan Tengah, dilatar belakangi pengalaman historis GKE dan warganya yang memiliki peranan besar membangun Kalimantan Tengah. Hal ini dimulai sejak masa kolonial, pergerakan kemerdekaan dan pembentukan provinsi Kalimantan Tengah. Kondisi riil dewasa ini, di mana GKE dan para anggota sudah tidak memainkan peran secara optimal di mata pemerintah dan masyarakat seiring pergeseran rezim kekuasaan politik dan pemerintahan sebagai faktor politik tidak langsung dan faktor politik langsung. Keberadaan GKE sebagai institusi yang memiliki eksistensi dalam kegiatan keagamaan serta juga memiliki basis massa yang besar maka dapat dijadikan sebagai pertimbangan elektoral dalam mendorong peran institusi dalam hal ini warga jemaat untuk tampil dalam pentas politik khususnya yang ada di Provinsi Kalimantan Tengah.

\section{DAFTAR PUSTAKA}

Badan Pekerja Harian Majelis Sinode GKE. Almanak GKE 2019. Banjarmasin : Sinode GKE, 2019.

Bayo, Longgina Novadona. "State Neglect, Church Decline, and Ascendent Adat: The Power Contestation in Adonara, Eastern Flores" dalam Jurnal Ilmu Sosial dan Ilmu Politik, Vol. 13, No. 2 (2009), h. 149-171.

Berkhof, H. \& I.H. Enklaar. Sejarah Gereja. Jakarta: BPK Gunung Mulia, 1996.

Budiardjo, Miriam dkk. Pengantar Ilmu Politik. Tangerang Selatan: Universitas Terbuka, 2014.

Kristiyanto, Eddy. Sakramen Politik: Mempertanggungjawabkan Memoria. Yogyakarta: Lamalera, 2008.

Ngelow, Zakaria J. "Turut Membina Indonesia Sebagai Rumah Bersama-Peran Gereja Dalam Politik Di Indonesia” dalam Jurnal Jaffray, Vol. 12, No. 2 (2014), h. 213-234. 
Noor, Firman. "Perilaku Politik Pragmatis Dalam Kehidupan Politik Kontemporer: Kajian Atas Menyurutnya Peran Ideologis di Era Reformasi” dalam Jurnal Masyarakat Indonesia, Vol. 40, No. 1 (2014), h. 57-74.

Palenewen, Jovano D. O. "Penerapan Patronase dalam Kemenangan Partai Keadilan dan Persatuan Indonesia pada Pemilu Legislatif Kota Bitung Tahun 2009". Tesis. Yogyakarta: Universitas Gadjah Mada, 2014.

Palenewen, Sheina M.S. "Pendampingan Pastoral Bagi Calon-Calon Legislatif Kristen di Wilayah Bitung III". Skripsi. Tomohon: Fak. Theologi UKI Tomohon, 2019.

Sastroatmodjo, Sudijono. Perilaku Politik. Semarang: IKIP Semarang Press, 1995.

Sholikhah, Amirotun. "Perilaku Politik Masyarakat Dalam Pemilihan Kepala Desa (Studi Pada Masyarakat Desa Kutasari Kecamatan Cipari Kabupaten Cilacap)" dalam Komunika, Vol. 8, No. 1 (2014), h. 79-97.

Usop, Kma M. Pakat Dayak: Sejarah Integrasi dan Jatidiri Masyarakat Dayak Daerah Kalimantan Tengah. Palangka Raya: Yayasan Pendidikan dan Kebudayaan Batang Garing, 1996.

Yewangoe, Andreas A. Tidak ada Penumpang Gelap: Warga Gereja, Warga Bangsa. Jakarta: BPK Gunung Mulia, 2009.

\section{Website}

Dewan Perwakilan Rakyat RI. "Undang-Undang Dasar Negara Republik Indonesia Tahun 1945” dalam http://www.dpr.go.id/jdih/uu1945 diakses 1 Januari 2020.

Komisi Pemilihan Umum RI. "Undang-Undang Nomor 7 Tahun 2017 tentang Pemilu" dalam https://jdih.kpu.go.id/detailuu-6c4d54564530516c4d3051253344 diakses 1 Januari 2020.

\section{Wawancara}

AN, Informan Bukan Pejabat Tinggi GKE, wawancara, 26 Oktober 2019.

HTP, Pendeta Pejabat GKE, wawancara, 24 Oktober 2019.

JHR, Informan Bukan Pejabat Tinggi GKE, wawancara, 24 Oktober 2019.

SFL, Pimpinan GKE, wawancara, 26 Oktober 2019.

SH, Caleg DPR RI, wawancara, 26 Oktober 2019.

TC, Pendeta GKE, wawancara, 24 Oktober 2019. 